\title{
MAPEANDO 0 TERRENO DA APRENDIZAGEM ORGANIZACIONAL E DAS COMPETÊNCIAS
}

\author{
Por André Luiz Fischer \\ Professor da USP \\ Coordenador do MBA-RH na FIA-USP e do Laboratório de Aprendizagem e Ensino FEA-USP \\ E-mail: afischer@usp.br
}

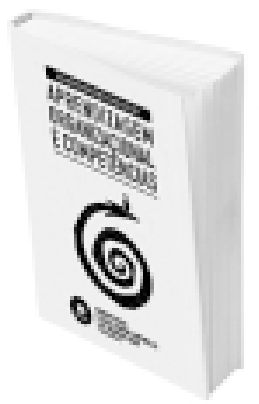

\section{OS NOVOS HORIZONTES DE GESTÃO - APRENDIZAGEM ORGANIZACIONAL E COMPETENNCIAS}

\author{
De Roberto Ruas, Cláudia Simone Antonello e Luiz Henrique Boff \\ (organizadores). \\ Porto Alegre: Artmed, 2004. 222 p.
}

Poucos temas vêm sendo tão debatidos pela literatura organizacional contemporânea como as noções de competência e de aprendizagem organizacional. A esse respeito assistimos nos últimos anos à produção de uma extensa bibliografia contendo análises teóricas e prescrições práticas oriundas de diferentes vertentes filosóficas, científicas eepistemológicas. Se de um lado tal dinamismo demonstra um campo teórico fértil, instigante e complexo, de outro resulta em um emaranhado conceitual difícil de ser decifrado e, por vezes, pouco útil para o avanço da teoria e da prática de gestão. A contribuição fundamental da obra organizada por Ruas, Antonello e Boff está no discernimento desse emaranhado, selecionando aquilo que realmente interessa ser considerado. Os autores realizam essa tarefa de forma abrangente, didática e recheada de casos el ucidati vos dos assuntos tratados.

Com os 11 trabalhos que compõem a coletânea Os Novos Horizontes de Gestão - Aprendizagem Organizacio- nal e Competências, são propostas duas árduas tarefas. A primeira consiste em organizar o percurso teórico dos conceitos "apren dizagem organizacional" e "competências", estabelecendo correntes, classificando-as e analisando-as criticamente. A segunda busca estabelecer as conexões entre esses dois conceitos, temas que, em geral, são tratados pela literatura de forma isolada.

Nos dois capítulos iniciais, Antonello e Ruas constroem mapas que nos introduzem nos dois terrenos conceituais. 0 primeiro analisa a metamorfose da aprendizagem organizacional revisando a literatura e identificando seis abordagens para categorizá-la, tendo a mudança organizacional como referência e el emento articulador. A amplitude do campo é muito bem demonstrada, assim como as dificuldades para se promover uma síntese conclusiva, ou mesmo definir uma opção orientadora, que se sobressaia entre as diferentes abordagens. Como reconhece a própria autora, não se trata de ir em "defesa de uma tese", mas de uma busca "didático-metodológica" no campo da aprendizagem organizacional.

A complexidade aumenta no segundo mapa, em que Ruas procura nos guiar para o ponto de intersecção entre a aprendizagem organizacional e a noção de competências. A "escola francesa" é esquadrinhada com importante passagem por Zarifian, uma vez que este é 0 autor que melhor contextualiza o foco em competências contraposto à idéia de qualificação. Qualificamos pessoas para a regularidade do mundo industrial, desenvolvemos competências para condições nas quais predomina o caráter eventual do trabalho pós-industrial. Portanto, a competência está sempre em formação, em movimento e aprendizagem. Sem essa contextual ização, como bem demonstra Ruas, o conceito perde sua razão de ser, sua justificativa concreta, tornando-se mero artifício gerencial de uso prático duvidoso. 0 texto de Ruas é corajoso, ao enfrentar o desafio de 
articular dois campos que não dialogam, inclusive na literatura internacional. Ponto al to do livro, certamente não haverá como falar de gestão por competências no futuro sem nos referirmos a esse trabalho.

A análise das teorias de estratégia e a competição baseada em competências é o foco do terceiro capítulo. Depois de uma visita aos clássicos de estratégia, reinterpretando o diálogo entre a teoria do posicionamento, em Porter, e a visão da firma baseada em recursos, em Prahalad, os autores encontram na aprendizagem gerencial 0 elo necessário para dar conta do ambiente dinâmico e imprevisível da atualidade. Conjugando a perspectiva da criação do conhecimento de Nonaka e Takeuchi com o pensamento construtivista, analisa-se uma experiência concreta realizada numa grande instituição bancária brasileira visando agregar competências gerenciais estratégicas ao seu corpo de gestores.

O último capítulo dessa primeira parte do livro retorna ao plano do indivíduo, definindo o que é o trabalhador do conhecimento e o que caracteriza o seu modo de trabal har. Demonstra que esse processo de trabalho é maior do que o simples processamento de informações, uma vez que implica cognição. Introduzindo a cognição em seu modelo, Boff e Abel defendem a idéia de que, se o processo de trabalho envolve conhecimento, é, por definição, um processo de autodesenvolvimento, uma forma particular de a pessoa criar competências ao mesmo tempo em que real iza a sua tarefa. Um maior detal hamento do que os autores entendem por cognição enriqueceria as conclusões do artigo.

$\mathrm{Na}$ segunda parte da coletânea é abordado um significativo número de casos de aplicação prática dos conceitos de competências e aprendizagem, a maioria deles voltada para o desenvolvimento gerencial e de executivos.
Cecília Oderich analisa três empresas de diferentes setores de atividade e constata que, embora o conceito venha se disseminando na gestão de Recursos Humanos, "ainda está um tanto confuso na aplicação prática". N os programas analisados, a maior fragilidade está na associação, ainda pouco clara e definida, entre competências organizacionais e individuais.

Constatações semelhantes aparecem no trabalho de Bittencourt, que trata de um interessante estudo de três empresas cujos gestores são interpelados sobre o modo como desenvolveram suas competências. A autora percebe, como características comuns aos três casos, uma lacuna entre o desenvolvimento das competências individuais e coletivas, e a tendência em ver esse desenvolvimento como evento isolado e não um processo contínuo, e uma preocupação excessiva com listas de atributos. Finaliza demonstrando que os gestores identificam nas experiências informais de aprendizagem suas principais fontes de desenvolvimento, valorizando mais o relacionamento interpessoal, 0 autodesenvolvimento e os desafios cotidianos do que os programas de treinamento previamente estruturados pela empresa.

Um dos aspectos mais controversos do debate sobre gestão de competências está na transição entre a competência individual e organizacional. Embora a intenção inicial da pesquisa de Becker e Lacombe se concentrasse no desenvolvimento da competência empreendedora, as autoras acabam encontrando uma excel ente oportunidade de explorar essa questão estudando gestores de empresas de base tecnológica incubadas em um centro especializado. 0 artigo éuma demonstração de como a noção de competênciase seus graus de complexidade podem apoiar as incubadoras no exercício de seu papel prioritário, de transformar seus incubados em empresários.
Complementam a obra dois textos que aplicam linhas teóricas distintas para analisar experiências de aprendizagem. No primeiro, Zimmer e Boff usam do conhecido modelo de Nonaka e Takeuchi para descrever a geração de conhecimento em equipes virtuais de trabal ho. Os ciclos de conversão do conhecimento são reconhecidos e as condições capacitadoras, identificadas e avaliadas. 0 segundo texto encerra a coletânea utilizando uma teoria menos comum em estudos nacionais: a aprendizagem na ação, aplicada em um grupo de gerentes do setor de construção civil. Analisando a evolução desses gerentes, os autores observam que essa modal idade de aprendizagem revel ou barreiras culturais que dificultam a agregação de competências de inovação.

A sensação, ao final da leitura da obra, é de que a opção dos organizadores foi pela maior abrangência possível, o que, em al guns dos textos, penaliza a profundidade de análise. Todos os ângulos e dimensões dos dois conceitos aparecem nos textos, do indivíduo à organização, passando pela coletividade e detendo-se mais longamente no gerente. Os fundamentos teóricos circulam do construtivismo às teorias sobre gestão estratégica, notando-se apenas a ausência da teoria institucional, que, certamente, traz uma contribuição significativa para as reflexões sobre aprendizagem organizacional. Para o leitor experimentado nesses campos teóricos, a obra representa uma oportunidade de rever conceitos e aprender com os novos ângul os de análise e as experiências práticas relatadas. Aos iniciantes, a leitura é um ótimo caminho de ingresso em temáticas complexas e multidimensionais que outras obras não conseguem tratar com o mesmo apuro teórico e qualidade didática. 